\title{
IMPROVING INTRA-ASEAN CONNECTIVITY AND INLAND WATERWAYS NETWORK FOR FURTHER INTEGRATION OF THE COASTAL SHIPPING AND TOURISM SECTOR DEVELOPMENTS
}

\author{
Hanizah Idris ${ }^{1} \&$ Hanafi Hussin ${ }^{2}$ \\ ${ }^{1}$ Main author, ${ }^{2}$ Corresponding author \\ Department of Southeast Asian Studies, Faculty of Arts and Social Sciences \\ University of Malaya \\ (wafa@um.edu.my, hanafih@um.edu.my) \\ DOI: https://doi.org/10.22452/jati.vol23no1.5
}

\begin{abstract}
Throughout history, the oceans have been important to people around the world as a means of transport and enhancing mobility. Connecting the archipelagic regions of ASEAN requires efficient and reliable shipping routes to enhance intra-ASEAN connectivity. The rivers and seas are also important for serving shorter trips like ferry services and recreational cruises. Today, the latter has recently experienced a tremendous boom and represents an increasingly lucrative source of tourist income. Therefore, this paper analyzes the importance of improving the intra-ASEAN connectivity and inland waterways network for further integration in the coastal shipping and tourism sector developments. The region comprises many important corridors; namely, the Great Mekong sub-region and the Brunei, Indonesia, Malaysia, Philippines-East Growth Area (BIMP-EAGA) sub-region that should be developed to enhance the economic development of the less developed areas, particularly in coastal trade. At the same time, the region also possesses many rivers including the Great Mekong River, which is shared by six countries, including China, and is significantly important for the socio-economic development of those countries. This is due to the highest concentration of population living along the river basin and some of them sharing water resources. Therefore, the inland waterways network should be developed for further integration in the tourism sector developments, for example, river cruises, heritage, and community-based ecotourism. Finally, the paper
\end{abstract}


identifies the key challenges faced by the region in improving the intraASEAN connectivity as well as managing its inland waterways network, particularly in coastal trade and tourism activities, and how it can be integrated regionally.

Keywords: Intra-ASEAN, connectivity, shipping, inland waterways, tourism

\section{Introduction}

Geographically, the Southeast Asian region comprises thousands of islands including important straits that form maritime Southeast Asia; namely, Indonesia, Malaysia, and the Philippines. In contrast, Mainland Southeast Asia comprises Thailand, Cambodia, Vietnam, Laos, and Brunei. The first and unifying feature of Southeast Asia is its maritime character as all countries except for Laos, are either an archipelagic or coastal state. This unique characterized where the seas link the archipelagic states poses a challenge in developing maritime transport. The Southeast Asian region has historically relied heavily on marine transport, which has been developed not only for trade but also for communications, administration, and political control (Leinbach \& Chia Lin Sien, 1989). Therefore, improving maritime connectivity is essential, not only to enhance mobility but also the economic activities within the region, and, especially, in the intra-ASEAN shipping movement and tourism development.

Maritime transport is the most important mode of transportation in terms of the traffic volume in international trade. However, many Southeast Asian countries, with the exception of Malaysia and Singapore rank poorly in the United Nations Conference on Trade and Development (UNCTAD) Liner Shipping Connectivity Index (Master plan on ASEAN connectivity, 2010). At the same time, connecting the archipelagic regions in ASEAN countries requires efficient and reliable shipping routes in order to enhance intra-ASEAN connectivity (Leinbach, R. Thomas \& Chia Lin Sien, 1989). In terms of inland waterways and rivers, most ASEAN countries are still developing and managing their waterways and rivers, particularly for transporting people and goods. Inland water transport (IWT) is one of the oldest economically and environmentally sustainable modes of transportation for passengers and cargo, and, in some areas, the only means of mobility to access basic services. Inland waterway transport is generally acknowledged as a clean, safe, and the most energy-efficient mode of transport when compared to land-based systems that are often challenged by congestion and capacity problems. 
Among the important waterways and rivers in the region are the Mekong River in Vietnam and the Chao Phraya River in Thailand. The Chao Phraya River, for example, is the backbone of the transportation system in Thailand. These waterways should be developed to serve the economy and social activities of the communities along the coast including tourism. For countries that are developing fast like Vietnam, the transport needs are growing even faster (Hanizah Idris, 2012, p. 47).

Therefore, this paper analyzes the importance of improving intraASEAN connectivity in the creation of new regional links and the expansion of the regional markets, and more efficient shipment of goods and people. This paper looks at the importance of developing the inland waterways network in the region for further integration in the tourism sector development that will benefit the poorer provinces along the routes. Finally, this paper also looks at the key challenges and obstacles faced to improve the maritime connectivity within the region, especially in managing the inland waterways of individual countries. Globalization is a process that describes the increasing economic, social and cultural integration of nations, and the forging of greater independence between them. Globalization is responsible for a rise in demand for transportation, especially shipping.

As far as tourism is concerned, global tourism is generally recognized as being one of the largest industries in the world and one of the most significant sources of employment and Gross Domestic Product (GDP). Tourism particularly benefits the economies of developing countries where most of the sector's tourism jobs and business are created. Today, the ASEAN region is well known for its outstanding tourist destinations like the beautiful beaches and islands that are located in Indonesia, Thailand, and Malaysia. The islands of Southeast Asia; namely, Bali Island in Indonesia, Phuket in Thailand, and Perhentian Island in Malaysia have become the most popular destinations in the world (http://perhentian.com). Apart from the island and coastal tourism, there are other tourism products and activities that can be promoted like the culture and heritage of the population that live along the coasts. Today, river cruises have become popular and have managed to attract tourists from all over the world. In European countries, river cruising is one of the main tourist attractions due to their longstanding efforts to manage their inland waterways and rivers to serve such purposes.

\section{Literature review}

Many of the studies conducted on infrastructure-based economic development combined some of the key policy characteristics inherited from the 
Rooseveltian progressivist tradition and Neo-Keynes economics based in the United States, which hold that a substantial proportion of a nation's resources must be systematically directed toward long-term assets, such as transportation and energy, and hard and soft infrastructure like roads, railways, ports, bridges, schools, hospitals, and many more. The origins of modern development economics are often traced to the need for and likely problems with the industrialization of Eastern Europe in the aftermath of World War II. Other related development theory, including Rostow's Linear Stage of growth model (Rostow, 1960), structural change-theory, focused on changing the economic structure of developing countries from primarily substance agricultural practices to more urbanized practices and a more industrially diverse manufacturing and service economy.

However, economic theory has evolved to account for the success and failure. Karla Hoff and Joseph E. Stiglitz argued that after more than 50 years, development is no longer primarily a process of capital accumulation but rather a process of organizational change (Hoff \& Stiglitz, 2001). This is evidenced in the less developed countries in Asia and the Pacific region. Todaro and Smith (2015) mentioned specifically the importance of formulating appropriate public policies that are designed to effect major economic, social, and institutional transformation in the shortest possible time. Among the most important and basic of the various measures is the fundamental responsibility of governments to establish a sound framework within which social and economic agencies, especially, can function efficiently. Other related literature on infrastructure and development includes Esterly and Robelo (1993), Canning and Fay (1993), Canning and Pedroni (2008), Van de Walle (1996), World Bank (1994), World Bank (2012), and Naoyuki Yoshino, Matthias Helbie and Umid Abidhadjaev (2018).

Infrastructure plays a critical role in generating inclusive economic growth and reducing poverty in Asia and the Pacific region. In the case of the Southeast Asian region, countries like Singapore and Malaysia managed to articulate a sound development policy after gaining independence focusing on infrastructure and economic development. Soon after the formation of ASEAN, the ASEAN five (Malaysia, Indonesia, Singapore, Thailand, and the Philippines) were heavily involved in international trade. Other countries in the region, including Lao PDR, Myanmar, Cambodia, and Vietnam, were left behind in the economic and infrastructure development. Lao PDR and Cambodia suffer the most chronic underinvestment in infrastructure and poor maintenance of the existing infrastructure. Several regional studies have estimated future infrastructure investment gaps in these areas including for 
the GMS sub-region and other economic-corridors in the region (Master plan on ASEAN connectivity, 2010). Funding institutions like the Asian Development Bank (ADB) continue to support greater transport connectivity and smoother trade between countries in the region and sustainable tourism in the subregions (Asian Development Bank [ADB], 2008). Priority has been given to transport projects including multisector projects in transport components in the less developed countries (Asian Development Bank [ADB], 2017).

Asia and the Pacific region is the world's fastest growing regional economy. Therefore, a major challenge for sustained regional growth and development is increased investment in the economy and social infrastructure. Governments provide the majority of the infrastructure, but, since 2005, private capital has increased in financing the infrastructure projects (Tang \& Metwalli, 2006). Governments in developing countries have been increasingly interested in attracting private capital for infrastructure investment. This includes Public-Private-Partnerships (PPP) projects, privatization, and other forms of private participation. Maritime infrastructure is crucial for the development of every region in the world and is of particular significance in the Southeast Asian region, which is the focus of this paper.

\section{Methodology}

The methodology used in this study is based on report analysis, which provides empirical evidence concerning maritime connectivity focusing on inter-Asian shipping and inland waterways networks, to promote further integration in the shipping and tourism sectors. Among the important references are reports from various sources like the Asia Development Bank, the World Bank, and the ASEAN Plan on ASEAN connectivity. Several studies show that investment in infrastructure development leads to economic growth. From these reports, it is evidenced that the maritime connectivity of the mainland Southeast Asian countries - Cambodia, Laos, and Vietnam - is still very poor. The Master Plan provides evidence concerning the achievement of maritime connectivity development to connect ASEAN countries through enhanced physical infrastructure development, effective institutions, mechanisms, and processes, and empowers people to people connectivity. The physical connectivity includes the challenges that need to be addressed including poor quality of roads, missing railway links, and inadequate maritime and port infrastructure. 


\section{Maritime Connectivity in the Southeast Asian Region}

In light of the rapid development in the region and the world resulting from globalization, Southeast Asian countries must continue to strive to maintain their central and proactive role by being the driving force in the evolving regional architecture by improving the physical connectivity among the countries. The region is still lacking physical infrastructure including good quality roads, and suffers from incomplete road networks; missing railway links; inadequate maritime and port infrastructure, including dry ports; inland waterways; aviation facilities; widening of the digital divide; and the growing demand for power (Master plan on ASEAN connectivity, 2010). This calls for upgrading the existing infrastructure, the construction of new infrastructure and logistics facilities, the harmonization of the regulatory framework, and the nurturing of innovation culture and heritage.

ASEAN, by means of regional cooperation, has identified gaps and promoted regional cooperation. For example, as far as missing links in the ASEAN highway network (AHN) are concerned these are located mostly in Myanmar with a total length of 227 kilometers. ASEAN has put in place numerous programs and initiatives for building and enhancing regional connectivity, and good progress has been made. As for rail infrastructure, the Singapore Kunming Railway Link (SKRL) flagship project was proposed at the fifth ASEAN Summit in December 1995 and targeted for completion by 2020. It covers several routes through Malaysia, Thailand, Myanmar and Kunming, China.

For maritime connectivity, connecting the archipelagic regions of ASEAN requires efficient and reliable shipping routes to enhance intraASEAN connectivity. In terms of sub-regional cooperation programs, many projects are being pursued both individually and collectively including the Greater Mekong Sub-region (GMS), comprising Cambodia, Lao PDR, Myanmar, Thailand, Vietnam, and China (1992); the Brunei Darussalam, Indonesia, Malaysia and the Philippines-East ASEAN Growth Area (BIMPEAGA) (1994); and the Indonesia, Malaysia and Thailand-Growth Triangle (IMT-GT) (1994). In order to achieve integration in the seas, especially to improve shipping routes, the Plan tries to implement the example of the Philippines Nautical Highway (Roll-on/roll-off (RO-RO) System. The RO-RO system is essential to achieve the goal of building efficient and reliable shipping routes to enhance connectivity (Toccheto, Tancredi, Araujo, \& Noronha, 2014). The RO-RO policy simplifies the process since it allows trucks, buses, and cars to roll on and off the vessel without unloading. In this sense, it 
saves time, cost, and equipment, and also makes some bureaucratic procedures unnecessary.

\section{A Vision for Regional Connectivity}

ASEAN is one of the most advanced regional integration blocs in Asia; it has been deepening its intraregional integration and moved toward the creation of the ASEAN Economic Community in 2015 (Review of maritime transport 2010, 2010). The implementation of the ASEAN Economic Community (AEC) blueprint accounts for the growth in intra-ASEAN trade over the years. The AEC blueprint also calls for the transformation of ASEAN into a single market and production base. In 2009, during the 15th ASEAN Leaders Summit, the Leaders declared that "intraregional connectivity within ASEAN and its subregional grouping would benefit all ASEAN Member States through enhanced trade, investment, tourism and development" (United States Agency for International Development [USAID], 2017). ASEAN has undertaken various measures and agreements relating to trade facilitation, such as the ASEAN Customs Agreement (1997), the ASEAN Framework Agreement on Facilitation of Goods in Transit (1998), the ASEAN Framework Agreement on Multimodal Transport (2005), and the implementation of the ASEAN Framework on Mutual Recognition Arrangements (Review of maritime transport 2010, 2010). The ASEAN Single Window Agreement (2005) allows trade information to be exchanged between government agencies within a one-stop facility, thereby simplifying trade procedures and reducing paperwork. National single window systems already exist in Malaysia and Singapore.

Many efforts, such as eliminating tariff protection, and introducing an ASEAN Free Trade Area (AFTA), have been made in some member states, particularly in the ASEAN 6 countries - Brunei, Malaysia, Indonesia, the Philippines, Singapore, and Thailand. Under AFTA, these six member states cut tariffs on nearly 8,000 items. However, four of the less developed ASEAN countries - Cambodia, Laos, Myanmar and Vietnam (CLMV) - require a further period to phase in the tariff elimination. The trends over the past decade for various indicators indicate the significant growth in inter-regional merchandise trade integration with ASEAN. The AFTA Agreement in 2010 boosted Intra-ASEAN trade, but then remained stable until 2014 at an average of 24 percent. Among the member states, Singapore ranked the highest in intra-ASEAN exports, followed by Malaysia and Thailand.

The Asian economic crisis in 1998, which severely hit the older marketoriented economies of Southeast Asia, also adversely affected the transitional economies of the CLMV countries (Tongzon, 2000). Intra-ASEAN trade has 
become increasingly important in these countries due to their recent adoption of outward-looking policies in their attempt to emulate the export-oriented growth development of their market-oriented neighbors (Tongzon, 2000). Since then, intra-ASEAN trade enjoyed an increase from 24 percent from 20002001 to 27 percent during 2007-2008 before once again being hit by the global economic crisis in 2009. However, Intra-ASEAN imports maintained a positive trend after recovering from the global financial crisis, especially in the CLMV countries. Singapore also ranked on top in importing products from the region, followed by Malaysia and Indonesia. However, intra-ASEAN imports in Singapore have decreased in recent years.

Even including trade with China, the intra-ASEAN trade does not exceed 40 percent of the total trade value. Despite the precipitous drop in global export demand, especially from the West, the extra-ASEAN trade still accounted for 75 percent of the region's trade in 2009 (Faustino \& Morales, 2010). Such low regional trade numbers can be partly attributed to the inadequate linkages between Southeast Asian countries, especially in Maritime Southeast Asia. ASEAN is beginning to address this issue, and in 2009, the ASEAN High-Level Task Force on Connectivity was established to develop a Master plan on ASEAN connectivity, which submitted during the 17th ASEAN Summit in Hanoi in 2010. The key strategies of ASEAN to enhance physical connectivity consist of (Toccheto et al., 2014):

(a) complete the ASEAN Highway Network,

(b) complete the implementation of the Singapore Kunming Rail Link (SKRL) Project,

(c) establish an efficient and integrated inland waterways network,

(d) accomplish an integrated, efficient, and competitive maritime transport system,

(e) establish integrated and seamless multimodal transport systems to make ASEAN the transport hub in the East Asia region,

(f) accelerate the development of ICT infrastructure and services in each of the ASEAN Member States, and

(g) prioritize the processes to resolve institutional issues in ASEAN energy infrastructure projects.

At the ASEAN Summit in Hanoi, the Philippines contributed its successful experience with the groundbreaking "roll-on, roll-off" nautical transportation policy, which brought down the cost of shipping among the Philippine islands by 30 to 40 percent. RO-RO allows cargo to be driven 
directly on and off ships, thereby eliminating the need for time-consuming and costly-handling and port-side equipment. Technical assistance to the Philippine government is provided by the Research, Educational and Institutional Development Foundation, with support from The Asia Foundation and the United States Agency for International Development (USAID). According to the previous Philippine President, Noynoy Aquino, once it is implemented, ASEAN connectivity will bridge our nation to our neighbors, shorten transfer distances, and open more economic opportunities for more people (Faustino \& Morales, 2010).

It is important to note that the envisioned regional RO-RO network would act as a complementary logistics backbone targeting underserved areas, rather than as a replacement of the existing shipping network. The RO-RO policy simplifies the process since it allows trucks, buses, and cars to roll on and off the vessel without unloading. A significant percentage of Southeast Asia's developing economies consist of agriculture where the decentralization effects of RO-RO shipping would expand the types of agricultural products feasible for international trade, and expand the markets available to rural farmers. $\mathrm{RO}-\mathrm{RO}$ is not a new shipping technology. $\mathrm{RO}-\mathrm{RO}$, along with customs immigration quarantine and security standardization, has been a strong contributing factor in European trade integration, especially for the Baltic States, Scandinavian countries, and the United Kingdom (Faustino, \& Morales 2010). In East Asia, RO-RO shipping is expanding. There are $15 \mathrm{RO}-\mathrm{RO}$ routes between China and Korea, 6 RO-RO routes between Japan and China, and 5 RO-RO routes between Japan and Korea (United Nations Agency and International Development [USAID], 2017). Figure 1 shows a vision for the Archipelagic ASEAN BIMP-EAGA RO-RO Network and also the Great Mekong Sub-region. According to a report by USAID (2017), RO-RO is a transport mode that can hasten ASEAN connectivity.

RO-RO, compared with conventional shipping and air transport, is faster and more affordable. More importantly, RO-RO is greener since its operations emit less carbon emissions compared to air transport. Moreover, it does not require a huge investment in port facilities, expensive cargo handling equipment (quay-side cranes) and deep draft/s. For developing economies with adequate funding for physical infrastructures, the RO-RO system presents a viable option. 
RO-RO shipping offers a path to increasing intra-regional trade and reducing dependence on extra-regional markets. In the case of the Philippines, RO-RO shipping allows more direct connections throughout the 7,000 scattered islands, increasing competition, reducing the turnaround time and reducing the shipping cost by up to 40 percent (Figures 2, 3, and 4). Apart from that, improving maritime economic corridors will improve the relations among neighbors as well as the flows of trade. The Japan International Cooperation Agency (JICA) has a project for a Maritime Economic Corridor in Southeast Asia, comprising Malaysia, Singapore, Indonesia, Brunei, and the Philippines.

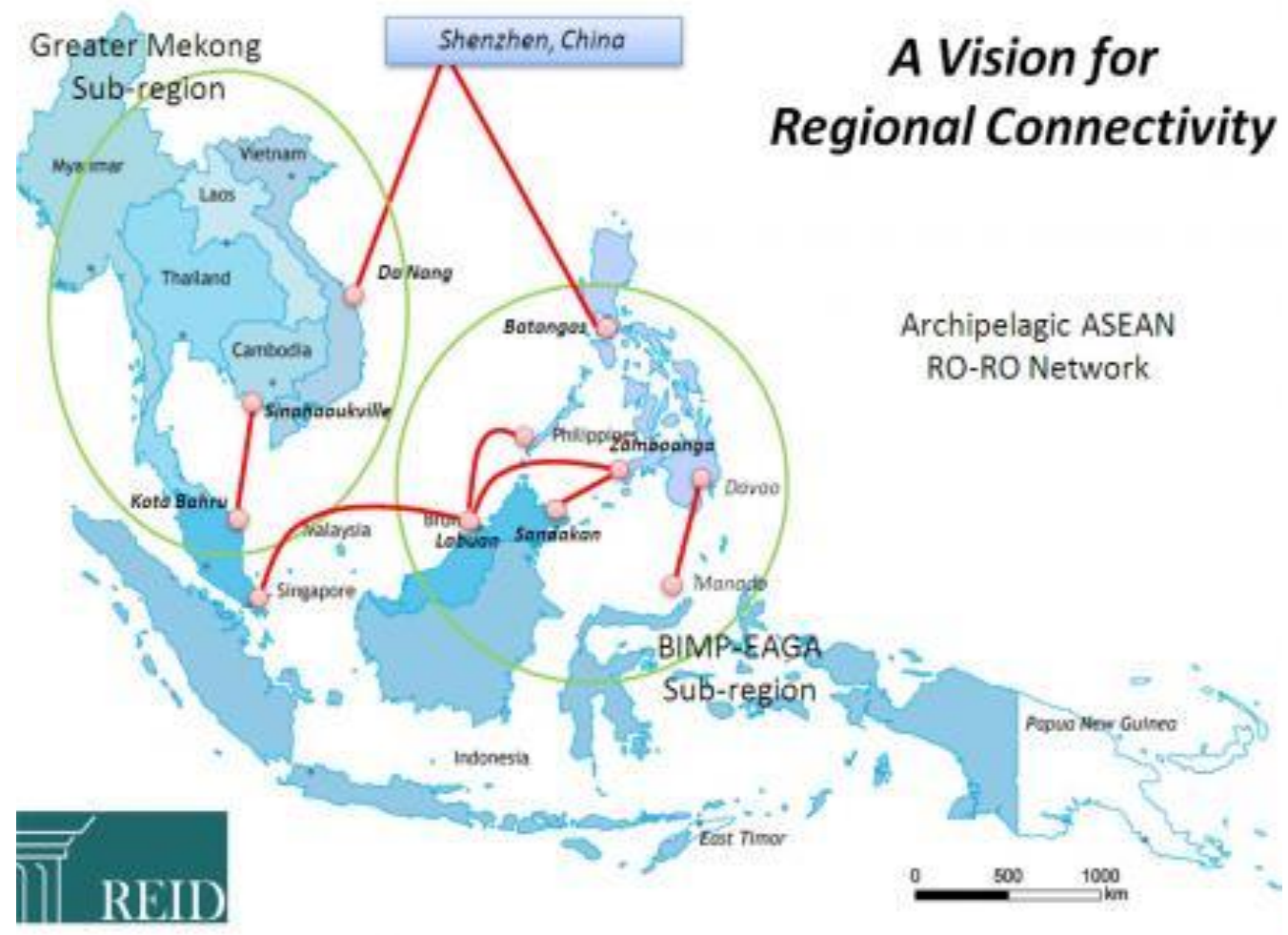

Figure 1: Map of Archipelagic ASEAN RO-RO Network

(Source: REID Foundation [2010].) 


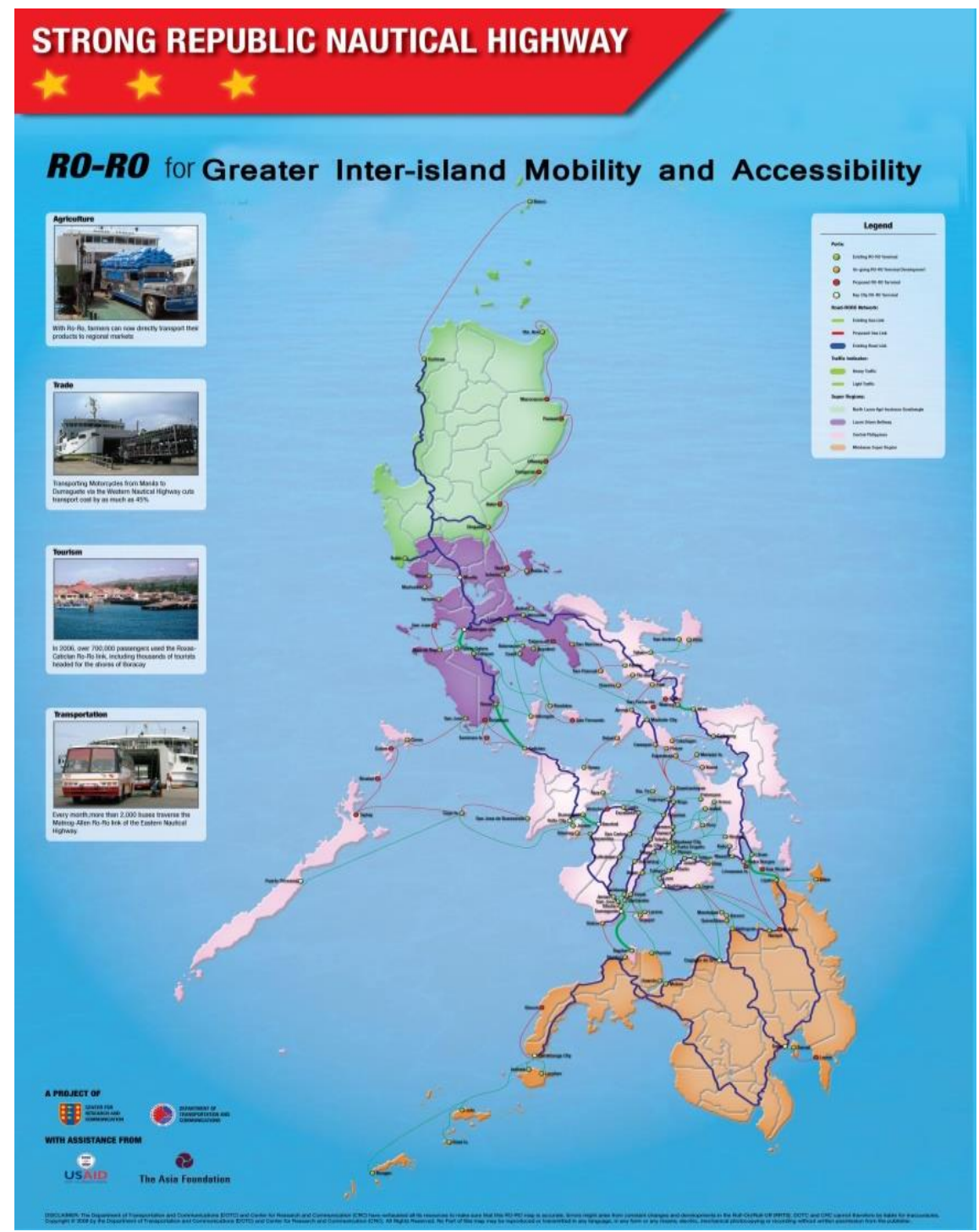

Figure 2: RO-RO for greater inter-island mobility and accessibility in the Philippines

(Source: Source: Ro-Ro Philippines, n.d.) 


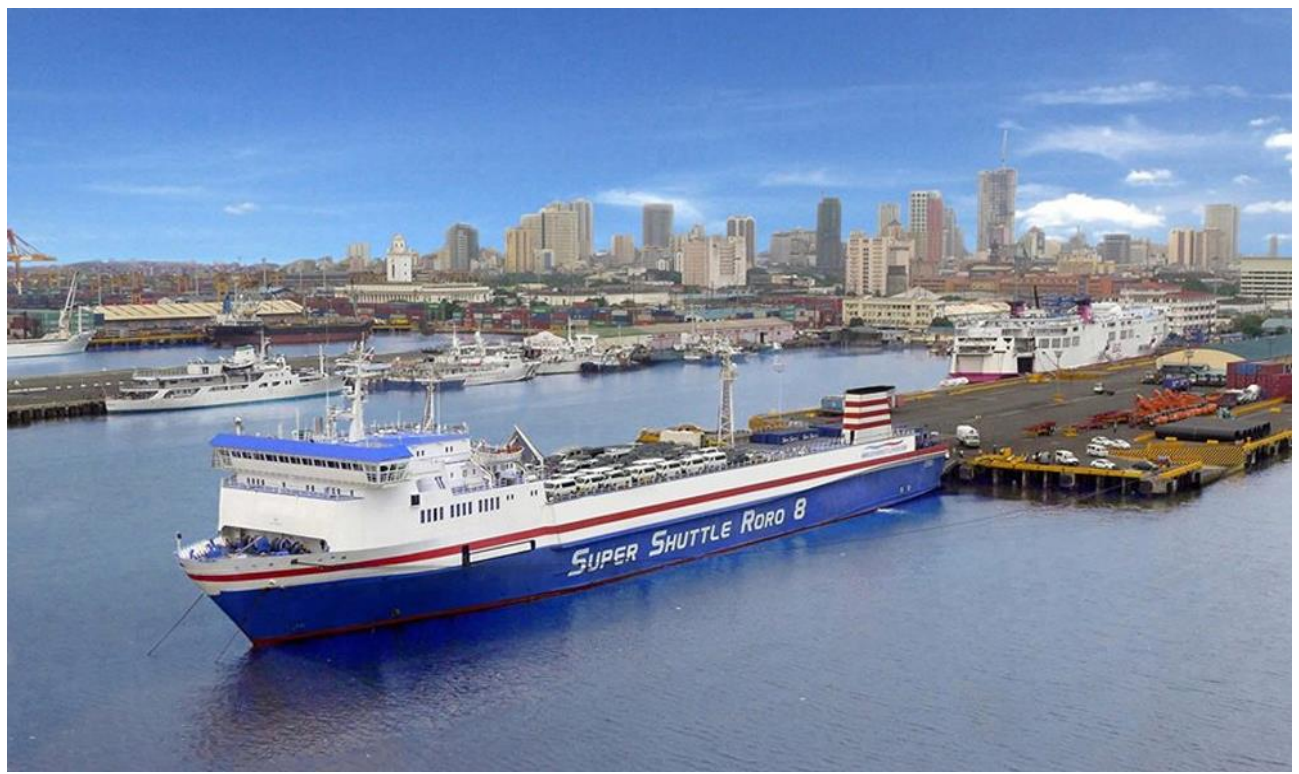

Figure 3: RO-RO vessel, Super Shuttle, Philippines

(Source: Ro-Ro Philippines, n.d.)

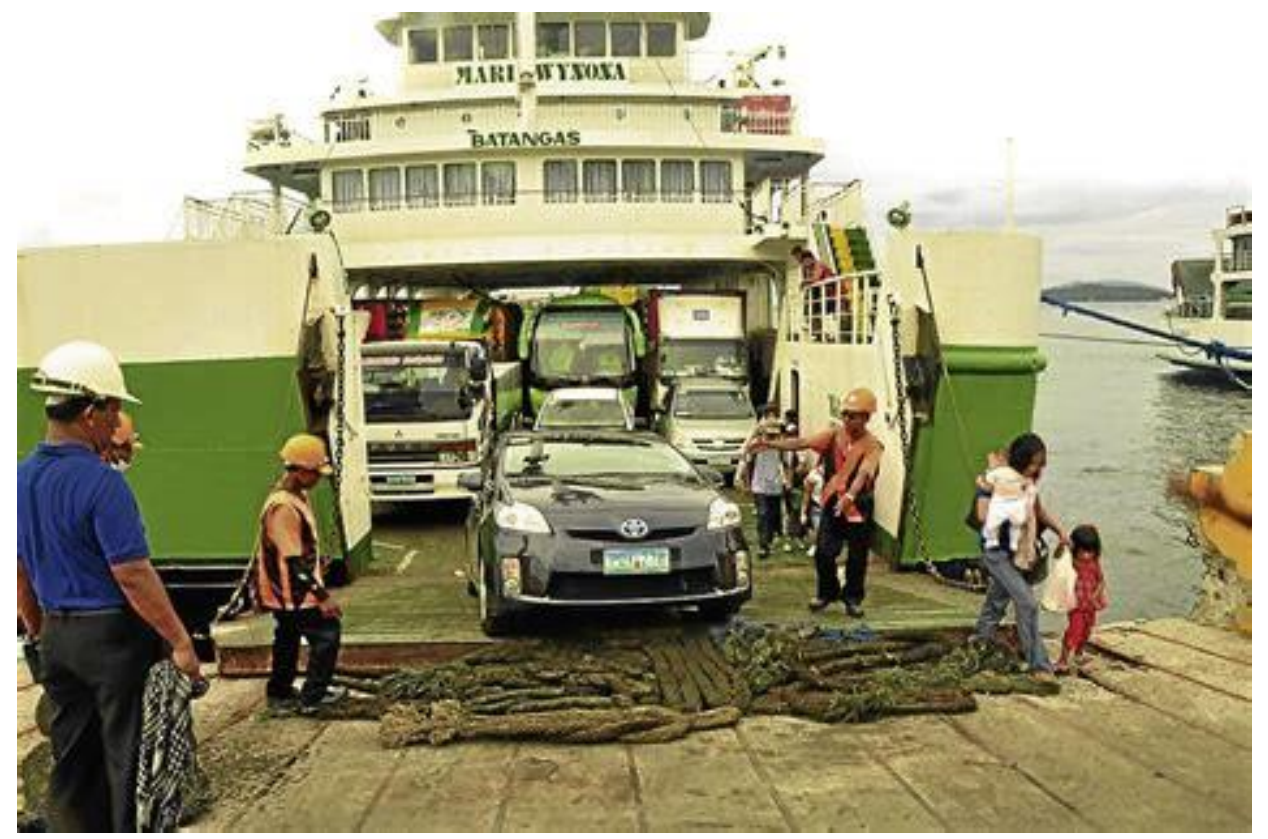

Figure 4: Ro-ro vessel transporting vehicles, Manila Port, Philippines

(Source: Source: Ro-Ro Philippines, n.d.) 
This initiative is part of the partnership between ASEAN and Japan for connectivity in the region. In 2013, the JICA Master Plan and Feasibility Study on the Establishment of an ASEAN RO-RO Shipping Network and Short Sea Shipping study showed that the new shipping route DAVAO-General SantosBitung (Sulawesi, Indonesia) would increase the trading opportunities for potential Philippines commodities to ASEAN markets. Commodities like processed seafood, tuna, Cavendish bananas and dried fruit products are among those that can be exported via the said route to the Philippine trade partners in BIMP-EAGA. Among the priority routes identified by JICA studies are the Dumai (Indonesia)-Malacca (Malaysia) and Belawan (Indonesia)Penang (Malaysia)-Phuket (Thailand) shipping routes (Figure 5).

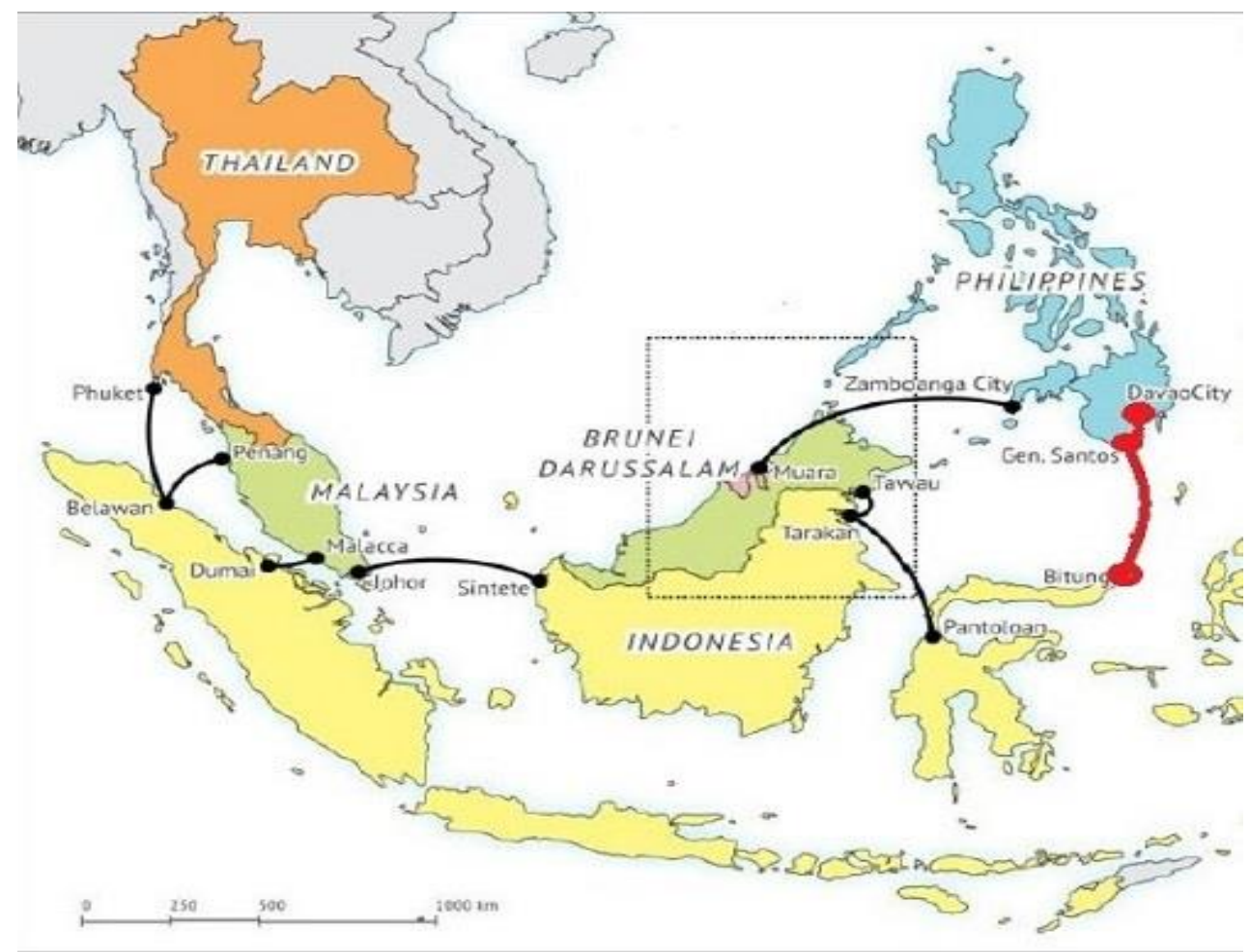

Figure 5: The RO-RO Shipping route network between Philippines and Indonesia (Davao-Bitung) and BIMP-EAGA and Belawan (Indonesia)-Penang (Malaysia)-Phuket (Thailand)

(Source: JICA ASEAN RO-RO) 
The Sub-regional initiatives for further integration of the coastal shipping and tourism sectors

Maritime connectivity remains a serious challenge in the region. Thousands of scattered, small, and isolated islands face enormous barriers, such as high transport costs and poor access to local and regional markets that hamper both trade and tourism. Indonesia and the Philippines are countries that possess thousands of islands. Indonesia possesses 17,000 islands, and the Philippines possess 7,000 islands. Parallel efforts under various sub-regional cooperation programs that, to varying degrees, address the physical, institutional, and people-people connectivity are also being pursued by ASEAN member states in order to enhance connectivity. The three major sub-regional initiatives in the ASEAN region include (Master plan on ASEAN connectivity , 2010):

(i) The Greater Mekong Sub-region (GMS), comprising Cambodia, Lao PDR, Myanmar, Thailand, Vietnam, and Yunan, China, established in 1992.

(ii) The Brunei Darussalam, Indonesia, Malaysia, and the Philippines-East ASEAN Growth AREA (BIMP-EAGA) established in 1994.

(iii) The Indonesia, Malaysia and Thailand-Growth Triangle (IMT-GT) established in 1992.

The sub-regional initiatives usually focus on the less developed areas of the ASEAN region with less favorable infrastructure and weak intraregional connectivity. This includes the management of the inland waterways network of those areas in order to enhance maritime connectivity, not only for the movement of goods but also for economic purposes like tourism and recreation development that will benefit the poor people living in the rural areas. Most projects involve infrastructure projects, and trade and transport facilitation as well as investment promotion and facilitation. For example, in the GMS, AFTA opened up the market and trade is expanding rapidly. However, the development of transport and logistics varies across countries. The cooperation between GMS is based on the integration of infrastructure (Figure 6). However, the physical development is inadequate in Cambodia, Laos, and Vietnam, which impedes the integration of transport and the development of logistics activities at the GMS (Transport and logistics in the Greater Mekong Sub-Region, 2010). Another crucial sub-region development is the BIMP-EAGA, which currently suffers from under-developed connectivity, one of the reasons for which is the poor maritime infrastructure. Such a situation requires attention since the sub-area accounts for the two largest archipelagos of the region (Indonesia and the Philippines) (Toccheto et al., 
2010). Several steps have been taken to develop RO-RO shipping connectivity within the countries in the sub-regional area, especially between the Philippines and Indonesia.

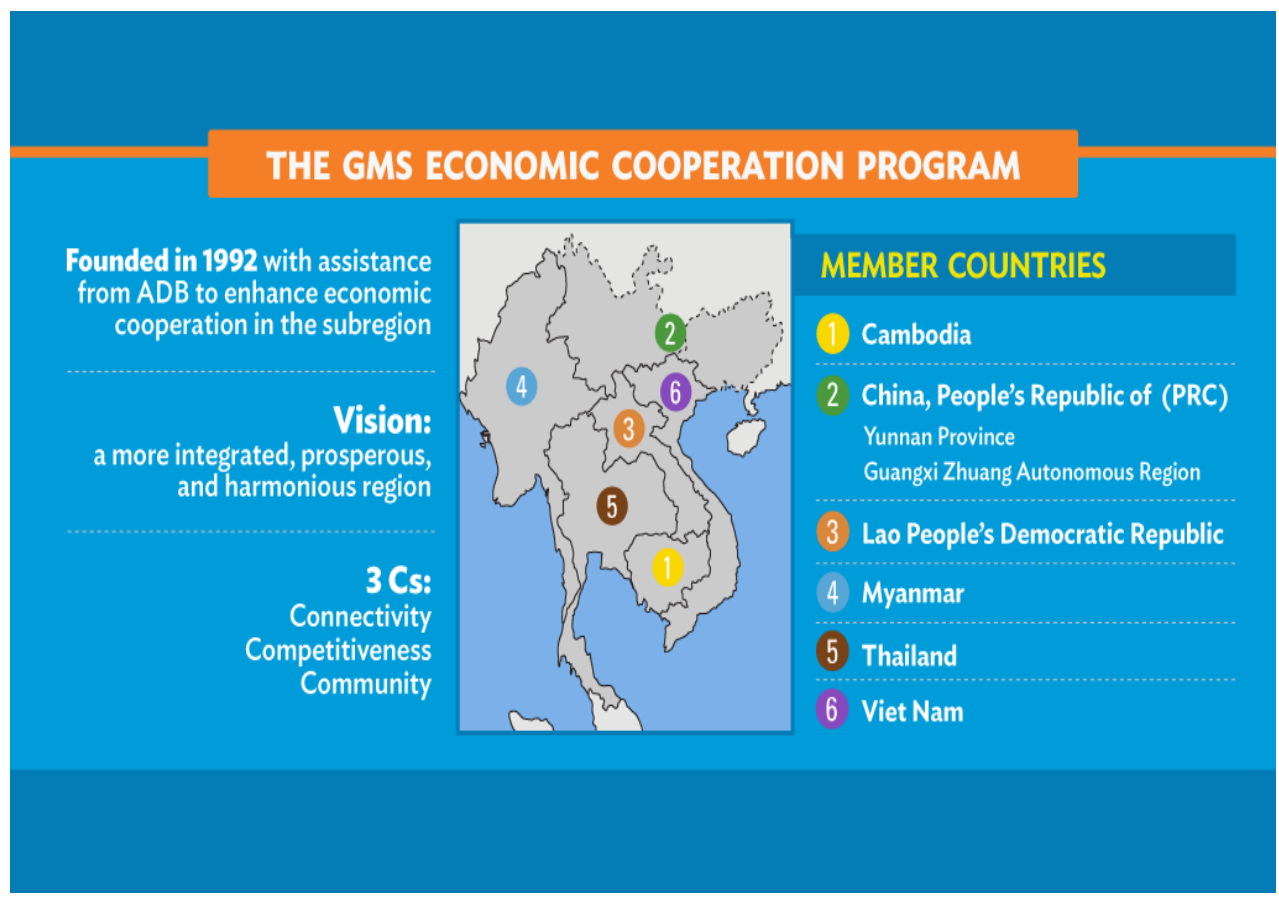

Figure 6: The GMS Economic Cooperation Program

(Source: The GMS Economic Cooperation Program, n.d.)

Figure 7 shows the IMT-GT sub-regional areas comprising Malaysia, Thailand, and Indonesia. Crucial to the development of this initiative is the establishment of connectivity through economic corridors including the Songkhla-Penang-Medan Corridor, the Straits of Malacca Corridor, and the most advanced in terms of transport connectivity, the Banda Aceh-MedanPekanbaru-Palembang Corridor and the Malacca-Dumai Corridor. ADB has initiated a study on the development of the IMT-GT economic corridors as a first step in implanting the following policies after a study made by the institution. Among the proposed policy framework and strategies for the maritime sector of IMT-GT are the IMT-GT support development of adequate port interfaces to facilitate seamless hinterland traffic movement as well as to increase the cargo potential of IMT-GT ports, especially Malacca and Singapore Singapore Straits recorded about 75,000 ships transiting annually (George, Abdul Samad, Hanafi Hussin, \& George, 2017). The IMT-GT also 
supports the growing demand for the transshipment of goods and passengers in the Straits of Malacca, as well as recognizes the role of tourism prospects between countries. The new terminal development at Melaka with the state of the art passenger terminal amenities including CIQ facilities may facilitate the movement of Ferry passenger traffic from Melaka to Dumai in Sumatra to encourage tourism.

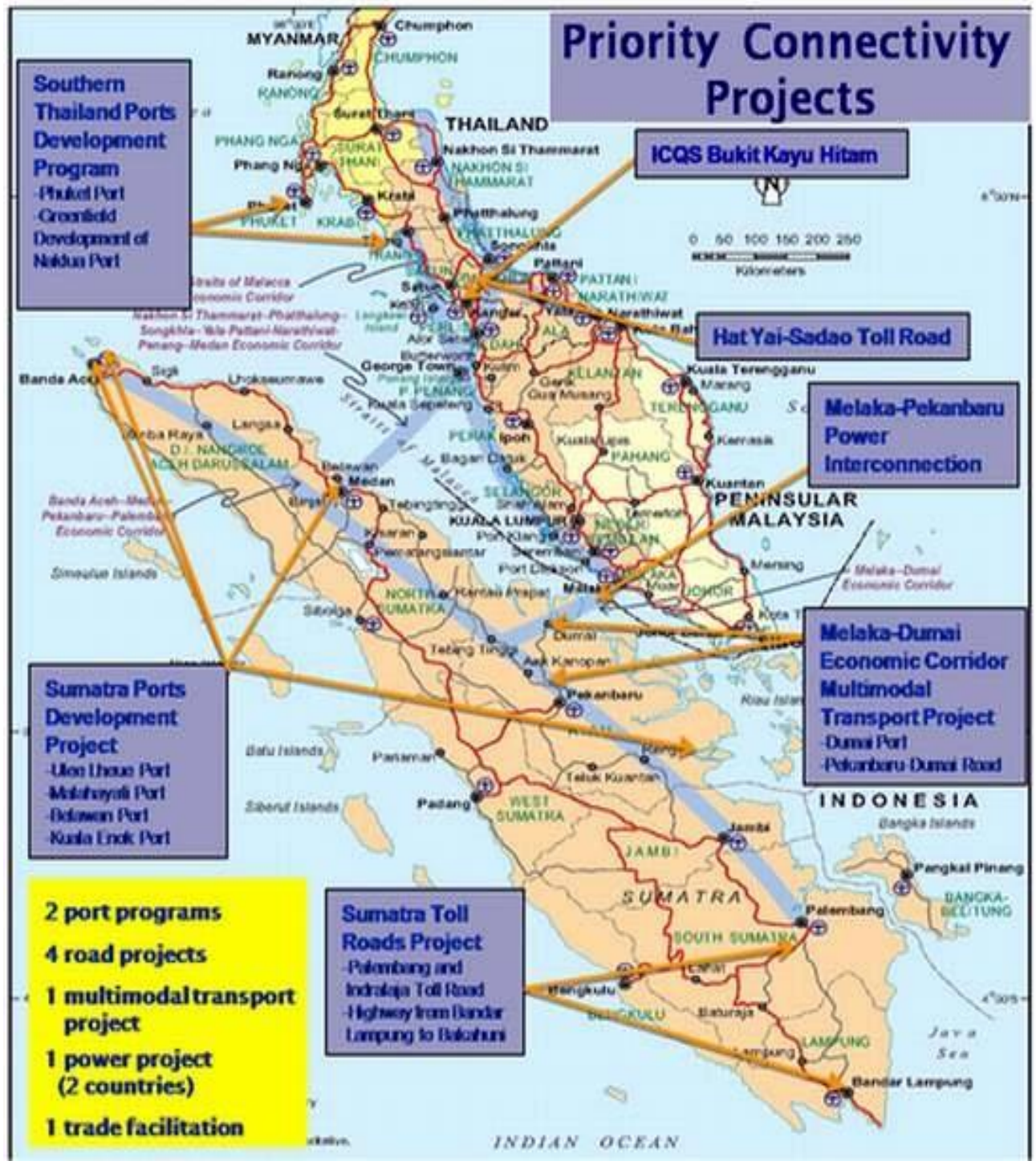

Figure 7: The IMT-GT Priority Connectivity Projects (Source: The IMT-GT Priority Connectivity Projects, n.d.) 


\section{Improving Inland Waterways Network in the sub-regional areas}

The IWTS in most Southeast Asian countries is planned, developed, operated, and maintained independently by the respective countries. The region comprises countries like Indonesia, Vietnam, and Myanmar, which possess long rivers that form an inland water network system that is prosperous economically. With Indonesia possessing a population of almost 270 million, and the combined population of mainland Southeast Asia together with Malaysia, the Philippines and Brunei being 250 million, the region is certainly blessed with vast opportunities for economic and social activities. This prompted the authorities to build basic infrastructure including rail and road links, while an inland water transport is an alternative mode of transport.

There has been a resurgence in commercial inland waterway transport, particularly for cargo and passengers, and especially in Asia and Europe. In Europe, the inland waterways have been used in many ways:

(i) For navigational uses including freight transport, passenger transport, and recreational navigation.

(ii) Waterway management uses like hydropower, environment/biodiversity, and flood alleviation.

(iii) Water-consuming uses, such as water supply and irrigation.

(iv) General recreation uses like heritage/tourism, land/city planning, and other water-related uses.

Southeast Asian countries comprise long inland waterway networks (IWNs) with Indonesia possessing the longest IWN of 21,579 kilometers, followed by Vietnam with 17,702 $\mathrm{km}$ and Burma with 12,800 km. The Mekong River is the backbone of the region, but is only partially navigable, except the stretch between Vietnam and Cambodia which is used extensively. The Great Mekong Sub-region (GMS) comprises six countries, Vietnam, Myanmar, Laos, Cambodia, Thailand, and Yunan, China. Yunan is part of the GMS and a less developed area in China. It is positioned as an international logistics hub for Southeast Asia, forming the gateway between ASEAN and China. Generally, inland water transport has been neglected so there is little use of inland water transport. Major investments are however driving the development, and the network is expanding rapidly. The construction of several other projects under the framework of GMS to connect Kunming, Lao, and Myanmar are under construction

Only Thailand and Vietnam have significantly upgraded their waterways through the efforts of the private sector. The inland waterways in 
Vietnam are well developed and provide an efficient transport network throughout the country (Transport and logistics in the Greater Mekong Sub-Region, 2010). In the case of Thailand, the inland water transport has been significantly upgraded by the effort of the private sector and the new Ayudhaya and inland container depot (ICD) Port of the CP group. Nevertheless, there is much room for further development since Thailand has about $3700 \mathrm{~km}$ of navigable inland waterways year-round. The inland waterways are mainly used to transport agricultural products and bulk products.

The inland waterways in Vietnam are relatively well developed and provide an efficient network throughout the country. They facilitate 25 to 30 percent of domestic cargo transport. Although there are more initiatives to develop the Mekong basin further, the port infrastructure is still underdeveloped. The lack of a supporting infrastructure and equipment as well as a multifunction of logistics supply chain with relatively high port charges negatively impact the competitiveness of the Vietnam port. Major projects are planned to upgrade the existing port infrastructure and to expand port capacity (Hanizah Idris, 2012). The Lao PDR and Cambodia are the least developed countries in the sub-region as well as in the region. As a landlocked country, Laos aims to benefit from the regional trade and economic growth by facilitating transport between the other countries, especially Thailand and Vietnam. However, the infrastructure in those countries is in poor condition and low in density.

\section{Promoting Water Transport for further integration in Tourism Sector Development}

Tourism is a major force for economic, social, and cultural change in the Southeast Asian region. In 2015, the tourism sector contributed 12.4 percent to the total ASEAN GDP, which was higher than the world average of 9.8 percent and the Asian average of 8.5 percent. Many factors contributed to the higher percentage including ASEAN's heritage and cultural attractions, improved tourist facilities, and affordable connectivity. According to UNWTO, the expansion of cultural tourism over recent decades has played a crucial role in the promotion and protection of tangible and intangible heritage as well as the development of arts, crafts, and creative activities. For example, the first UNWTO/UNESCO World Conference on Tourism and Culture, held in Siem Reap, Cambodia in 2015, brought together for the first time the ministers of tourism and ministers of culture with the objective being to identify the key opportunities and challenges for stronger cooperation between the closely interlinked sectors of tourism and culture (United Nations Tourism World 
Organization [UNTWO, 2015]). The conference participants endorsed the Siem Reap Declaration on Tourism and Culture.

At the regional level, several ASEAN initiatives in the tourism sector have been undertaken over the years under the Roadmap for Integration of Tourism Sector 2004-2010 to further promote ASEAN as a tourist destination through the liberalization of tourism and travel related services, upgrading the tourism infrastructure, enhancement of skills of tourism-related personnel, and encouraging greater participation from the private sector in the development of the tourism sector (Master plan on ASEAN connectivity, 2010). Tourism has also been promoted in terms of sub-regional economic cooperation, especially at the GMS. Three countries - Cambodia, Lao PDR and Vietnam - shared \$35 million in project funding with the aim being to reduce poverty and boost economic growth in ways that are respectful to the environment and culture.

These interventions have had a major impact on the tourism sector of the GMS countries. For example, foreign arrivals in the GMS countries increased to over 30 million in 2010 from less than 17 million in 2002. In 2007, GMS tourism resources attracted 27 million international tourists and generated \$15.6 billion in receipts (Asia Development Bank [ADB], 2008). Thailand is the dominant player in the GMS tourism sector, receiving over half of all international arrivals in 2007. Today, Vietnam is enjoying the benefits and the prosperity from the tourism development in the GMS. Tourism business contributed 7 percent of the gross domestic product, and the government is welcoming 17 million tourists in 2018, an increase of 30 percent from last year. In Vietnam, the tourism business is flourishing not only in the popular destinations but also in the northern part of the country where there are high rates of poverty and ethnic minority populations (Asia Development Bank [ADB], 2008). It was projected at the time that by 2015, the number of visitors from abroad would top 50 million and help sustain 7.3 million jobs in the GMS.

If they are to attract more tourists, the GMS countries, particularly Vietnam, Cambodia and Lao PDR, need to improve their infrastructure including their inland waterway network system. For example, in Siem Reap in Cambodia, funding enabled the city to replace its antiquated water system with new sewers, drainage canals, and stormwater chambers. In Vietnam, the project's My Tho Tourist River Pier Development built a landscaped public park at Tien Giang, reinforced the river embankment with floating steel wharves, and added a passenger. At the moment, most rivers and canals are not properly managed regarding their cleanness despite their importance as a means of transportation for goods and communities living along the river; as 
shown below. In the case of the Chao Phraya River, more emphasis should be given by the government to improve the inland waterways network to further integrate the tourism culture and heritage developments in Thailand.

\section{River transportation in Bangkok, Thailand}

Thailand possesses great rivers like the Menam Chao Phraya. It is the largest watershed in Thailand, and covers approximately 35 percent of the nation's land. Several canals, also known as "Khlong", have been made in the past, shortening the trip from the city to the sea. Boats are a great way to get around the famous Riverside area with its many historical attractions, temples, and architecture, and also to explore the "khlongs" (canals) for a glimpse of Bangkok from yesteryear (Figures 8 \& 9). Several kinds of boats (express boats, river taxis, and tail-boats) run up and down the Chao Phraya River connecting with the local suburbs on the Thonburi side and along the river, while ferries can be used to cross the river at various points (hotel.com [n.d.a]). Stretching west to east across the map of Bangkok, Khlong Saen Saeb begins in the Old City, near the Mahakhan Fortress at the end of Ratchadamnoen Road, and runs all the way to Chachoengsao Province, where it ends by flowing into the Bang Pa Kong River. It cuts through central areas like Phayathai, Pratunam, Chitlom, Nana, Asok Road, Thonglor, and Ekkamai, running parallel to the Phetchaburi and New Phetchaburi Roads, before turning up Ramkhamhaeng Road and on to Bangkapi (Figures 10, 11, \& 12) (hotel.com [n.d.b]).
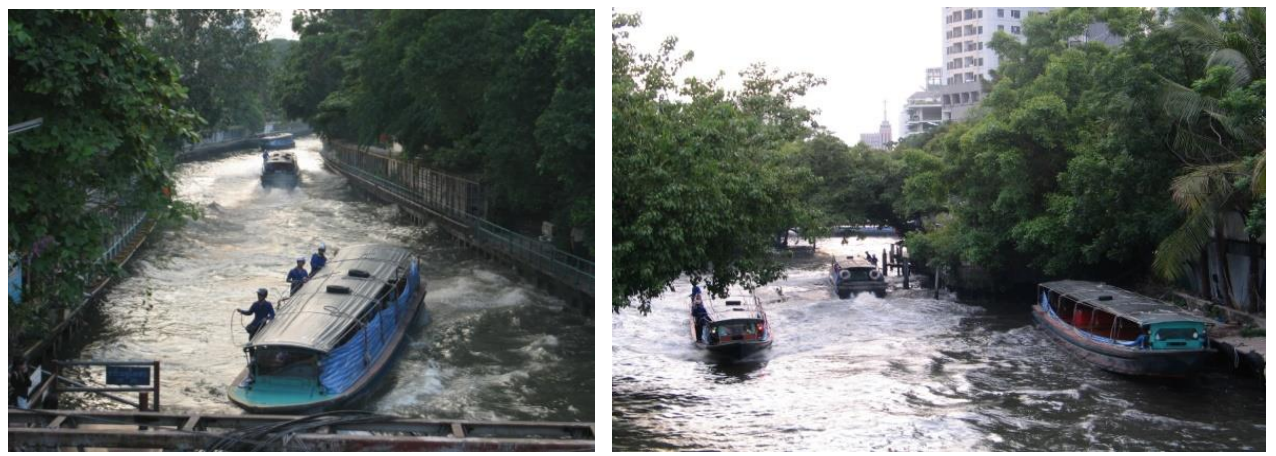

Figures 8 and 9: Boat service at Khlong Saen Saeb, Bangkok, Thailand (Source: Hanafi Hussin, fieldwork.) 

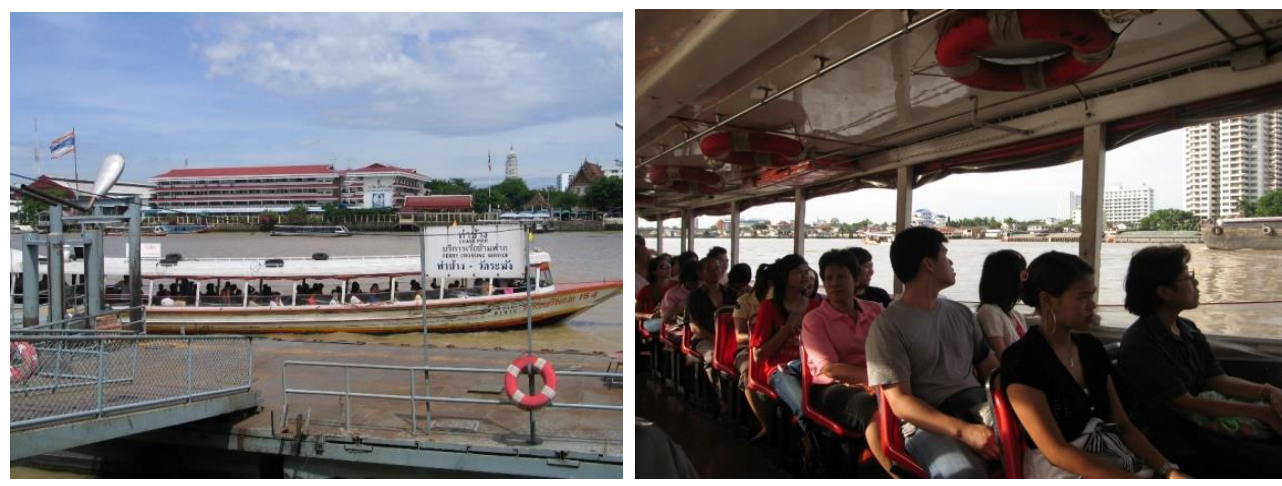

Figures 10, and 11: Riverboats and ferries at Chao Phraya River, Bangkok (Source: Hanafi Hussin, fieldwork.)

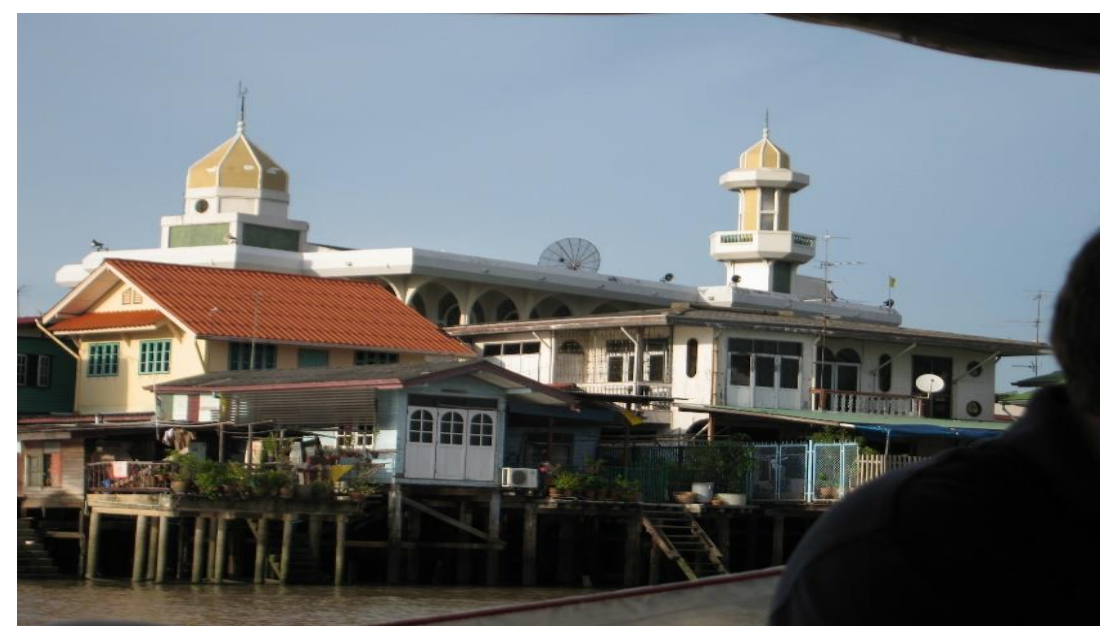

Figure 12: Riverboat and ferries at Chao Phraya River, Bangkok where the visitors and tourists can enjoy the riverscape of Bangkok

(Source: Hanafi Hussin, fieldwork.) 
Water for transporting people and goods
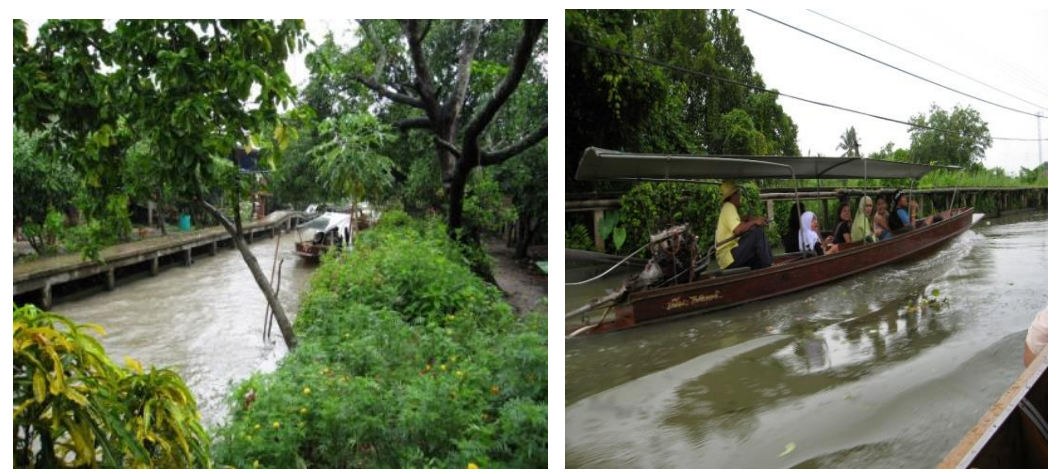

Figures: 13 and 14: Appreciating canals as a traditional mode of transportation in Thailand

(Source: Hanafi Hussin, fieldwork.)
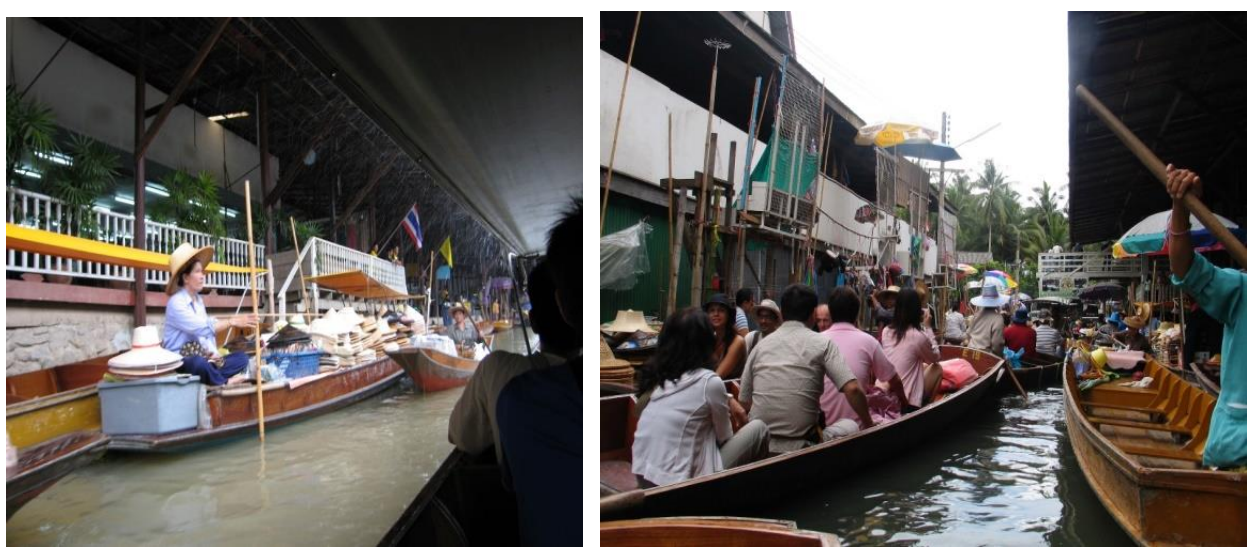

Figures 15 and 16: Exploring water as heritage - mode of transportation and livelihood for income sources - traditional market and floating market (Source: Hanafi Hussin, fieldwork.) 
Promoting Chao Phraya river transport as heritage and cultural product for tourism source of income
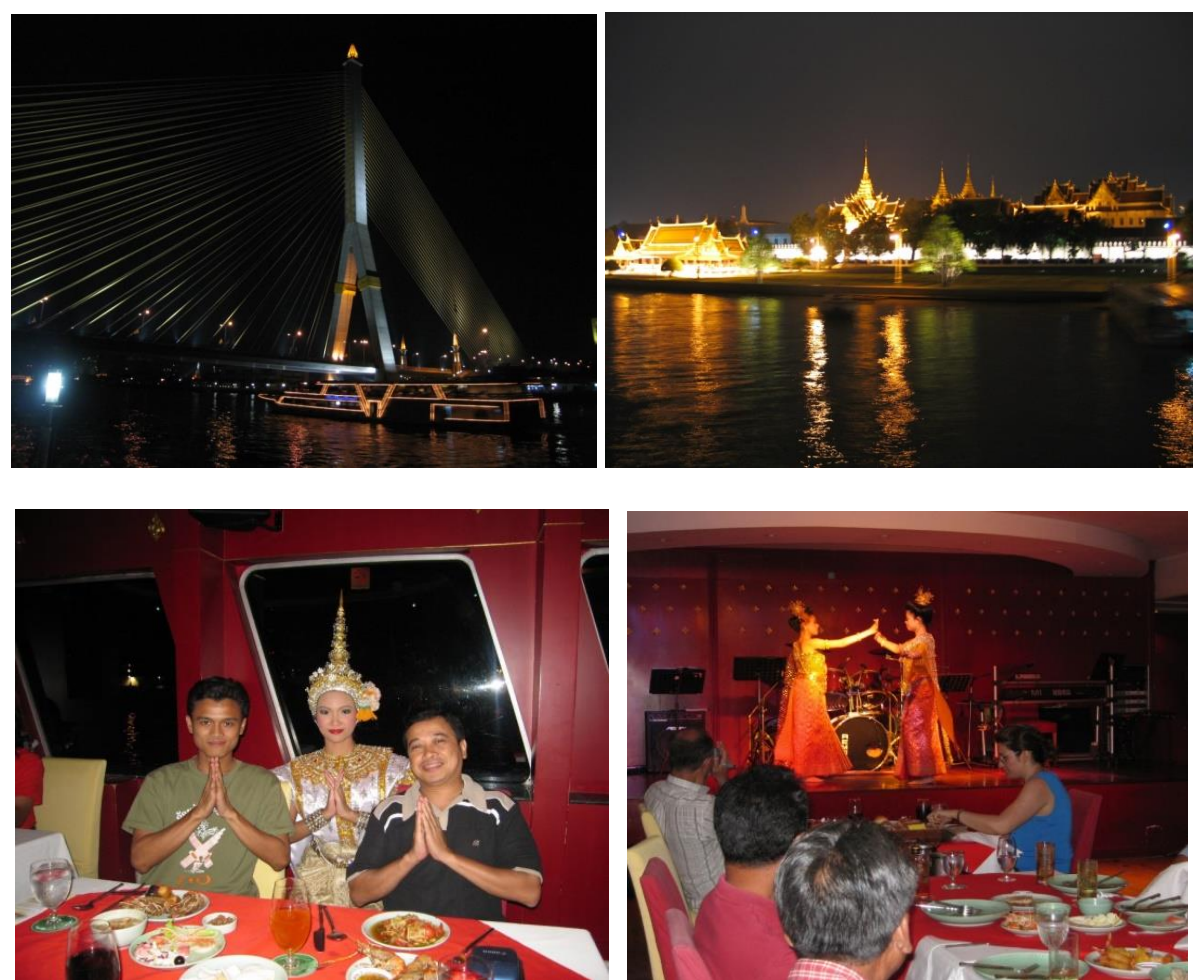

Figures 17, 18, 19, \& 20 (from top right to the left): Night River Cruise along Chao Phraya River - Package for Tourism: visitors and tourists can enjoy colorful and spectacular Bangkok in the evening

(Source: Hanafi Hussin, fieldwork.)

\section{Challenges}

The Southeast Asian countries are still in the stage of developing their intraASEAN connectivity in terms of intra-regional maritime transport. Sea transport is the most used mode of transport in intra-ASEAN trade, and, therefore, plays a significant role in the export and import activities of the region. However, there are many challenges in implementing greater connectivity and accessibility between ASEAN regions as listed below:

i) Maritime infrastructure (port, maritime services, and port performance) 
ii) Economic viability

iii) Effective regulatory framework

iv) ICT Infrastructure Development

v) The funding mechanism for participation of low-income countries

Institutional connectivity - transport facilitation, free flow of goods, services, investments, and the free flow of skilled labor

Greater connectivity within ASEAN poses its own challenges in terms of crossborder procedures. ASEAN addresses this issue through the initiative to improve the cooperation between immigration institutions in the member states, as well as through building and modernizing the capability of the immigration institutions; as reflected in the ASEAN Plan of Actions for Cooperation in Immigration. Apart from the regulatory environments that need to be established, one way to facilitate the process is by developing the sub-regional initiatives, such as GMS, BIMP-EAGA, and IMT-GT to promote greater cooperation between Southeast Asian countries. This will not only enhance the intra-ASEAN shipping network but also economic development in those areas, especially in the tourism sector by improving the inland waterways network to serve multiple purposes like ferry cruises and heritage tourism based on the cultural activities of the communities. Sub-regional cooperation initiatives with the participation of ASEAN's external partners also play an increasingly important role in contributing to narrowing the gap among the ASEAN countries.

\section{Conclusion}

Overall, given the larger geographical coverage and synergy that can be generated among the sub-regions, and despite the many challenges in developing maritime connectivity within the region, there is a need to promote the links and interfaces among the various sub-regions to broaden and deepen these partnerships. Connecting the archipelagic regions of ASEAN requires efficient and reliable shipping routes to enhance intra-ASEAN connectivity. The result of the initial impact assessment of the Philippines Nautical Highway, also referred to as the Roll-on/roll-off (RoRo) System, demonstrate significant benefits in terms of a reduction in cost, the creation of new regional links, and the expansion of regional markets. In terms of sub-regional cooperation, ASEAN makes available a broader regional framework in which these sub-regional programs can carry out their work since many ASEAN and GMS, BIMP-EAGA, and IMT-GT activities share the same purpose. The financing of sub-regional infrastructure projects faces more complex 
challenges, which make the process more complicated. Although ASEAN as a regional organization has formulated various transport development programs among State Members, there are still many gaps and challenges that should be addressed in improving intra-ASEAN connectivity and accessibility to promote further integration in the development of the intra-ASEAN coastal shipping and tourism sector within the region and beyond.

\section{Acknowledgments}

The authors would like to thank the Institute of Ocean and Earth Sciences and the Faculty of Arts \& Social Sciences, University of Malaya, for supporting the research activities related to maritime development in Southeast Asia.

\section{References}

Asian Development Bank (ADB). (2008). Retrieved from http://www.adb_2008_.pdf

Asian Development Bank (ADB). (2017). Retrieved from http://www.adb_2017.pdf

Canning, D., \& Fay, M. (1993). The effect of transportation networks on economic growth. Columbia University Working Paper 653a. New York, NY: Columbia University.

Canning, D., \& Pedroni, P. (2008). Infrastructure, long run economic growth, and causality tests for cointegrated panels. The Manchester School, 76(5): 504- 527.

Faustino, J., \& Morales, J. (2010, 22 September). Philippines spearheads ASEAN effort to establish regional RO-RO sea transport network. In Asia Weekly Insights and Analysis, Asia Foundation. Retrieved from http://asiafoundation.org.2010/09/22/philippines-spearhead-ASEANeffort-to-estavlish-regional-ro-ro-sea-transport-network

George, M., Abdul Samad Shaik Osman, Hanafi Hussin, \& George, A. R. (2017). Protecting the Malacca and Singapore Straits from ships' atmospheric emissions through the implementation of MARPOL Annex VI. The International Journal of Marine and Coastal Law, 32, 95-137.

Hanizah Idris. (2012). The Vietnam's port development in the $21^{\text {st }}$ century"Roads without bridges, bridges without roads". JATI-Journal of Southeast Asian Studies, 17, 43-56. 
Hoff, K., \& Stiglitz, J. E. (2001). Modern economic theory and development. In G. Meier \& J. E. Stiglitz (Eds), Frontiers of development economics: The future in perspective (pp. 389-459). New York: Oxford University Press. Retrieved from http://siteresresources.worldbank.org.pdf.

Hotel.com (n.d.a). Bangkok.com-River boats \& ferries in Bangkok: Getting around Bangkok. Retrieved from http://www.bangkok.com/information-travel-around/boats-ferries.htm

Hotel.com (n.d.b). Bangkok.com-Khlong Saen Saeb: Route guide and how to use it. Retrieved from http://www.bangkok.com/attractionwaterway/khlongs-khlong-saen-saeb-boat-route-guide.htm

Leinbach, R. T., \& Chia Lin Sien. (1989). South-East Asian transport: Issues in development. Kuala Lumpur: Oxford University Press.

Master plan on ASEAN connectivity. (2010). Jakarta: ASEAN Secretariat. Retrieved from http://www.asean.org/Master_Plan_on_ASEAN_Connectivity.pdf

REID Foundation. (2010, 22 September). Retrieved from http://www.asiafoundation.org/2010/09/22-philippines-spearheadasean-effort-to-establish-regional-ro-ro-sea-transport-network/

Review of maritime transport 2010. (2010). New York: United Nation on Conference, Trade and Development (UNCTAD). Retrieved from https:/www.unctad/org/en/publicationsLibrary/rmt2010

Ro-Ro Philippines. (n.d.) Retrieved from https://www.bing.com/images/search?q=roro\%20routes

Rostow, W. W. (1960). The stages of economic growth: a noncommunist manifesto. Cambridge: Cambridge University Press.

Tang, R. T. W., \& Metwalli, A. M. (2006). Mergers and acquisitions in Asia a global perspective. New York: Routledge.

The GMS Economic Cooperation Program. (n.d.) Retrieved from http://www.bing.com.images

The IMT-GT Priority Connectivity Projects. (n.d.) Retrieved from http://www.bing.com/images

Toccheto, J. S., Tancredi, L., Araujo, R. Z. \& Noronha, R. S. (2014). Maritime connectivity in the Asia Pacific region. UFRGSUN (UFRGS Model United Nations), Vol. $\quad 2 . \quad$ Retrieved from http://www.ufrgs.br/ufrgsmun/2014/files/ADB.pdf

Todaro, M. P., \& Smith, C. S. (2015). Economic development (12th ed.). Boston: Pearson.

Tongzon, L. Jose. (2000). The Asian economic crisis: Socio-economic implications for the transitional economies. In Abdul Rahman Embong 
\& J. Rudolph (Eds.), Southeast Asia into the twenty first century crisis and beyond (pp. 70-81). Bangi: UKM Press.

Transport and logistics in the Greater Mekong Sub-Region. (2010). Bangkok: Embassy of the Kingdom of the Netherlands. Retrieved from https://data.opendevelopmentmekong.net/dataset/ba663577-f080-48d7ae52-ec415691e82a/resource/ecc05004-819e-4aa6-9abe8cd1cf68c3a3/download/transport-and-logistics-in-the-greater-mekongregion.pdf

United Nations Agency and International Development (USAID). (2017). Enhancing ASEAN connectivity: The ASEAN RO-RO initiative. Retrieved from http://www.pdf.usaid.gov/pdf_docs/PAOON1N9.pdf

United Nations Tourism World Organization (UNTWO). (2015). Annual report 2015. Retrieved from http://www.untwo.org/publication/untwo-annualreport-2015

Van de Walle, D. (1996). Infrastructure and poverty in Viet Nam. LSMS Working Paper. No. 121. Washington, DC: The World Bank.

World Bank. (1994). World development report 1994: Infrastructure for development. Washington, DC: World Bank. Retrieved from http://www.worldbank.org.1994.pdf

World Bank. (2012). Impact evaluation for infrastructure: general guidance and existing evidence. Washington, DC: World Bank. Retrieved from http://www.worldbank.org_2012_pdf

Yoshino, N., Helbie, M., \& Abidhadjaev, U. (Eds). (2018). Financing infrastructure in Asia: Capturing impacts and new sources. Tokyo: Asian Development Bank Institute.

Date Received: 15 November 2017 Date of acceptance: 15 April 2018 